\title{
Graphene : An Out Standing Material
}

\author{
Razika Zair Tala-Ighil ${ }^{1,2}{ }^{*}$
}

${ }^{1}$ Research Unit on Materials, Processes and Environment, URMPE Unit, University M'hamed Bougara Boumerdes, 35000 Boumerdes, Algeria

${ }^{2}$ Institute of Electrical and Electronic Engineering, M'hammed Bougara University, 35000 Boumerdes, Algeria

\begin{abstract}
In photovoltaics, research is aiming to investigate new materials able to push the efficiency limit for solar cells towards the highest values without increasing the fabrication cost.

This paper presents a review about graphene material and its potential use in all technological fields. Due to its high conductivity, transparency and amazing properties. It seems that it has an important place in the next generation of solar cells instead of silicon or thin film based solar cells, researchers found diverse applications for graphene in nanoelectronics, aviation, industry, transport, biomedecine and others.

This paper present a review about the state of art about the graphene material in photovoltaic solar cells where very interesting efficiencies were recorded.
\end{abstract}

Keywords: Graphene, 2D material, Solar cell, Conversion efficiency.

\section{INTRODUCTION}

\section{What is Graphene}

Carbon is a nonmetallic element that belongs to column IV in the Mendeleev table of elements. It is widely distributed in the Earth and all living creatures [1].

Carbon may crystallize in diamond structure to be the most expensive material in the world [2], graphite in hexagonal structure [3], and in diamond-hexagonal as synthetized firstly by F.P. Bundy et al. [4]. This was possible by applying a temperature of $1000{ }^{\circ} \mathrm{C}$ and pressure $130 \mathrm{kbar}$. They obtained an hexagonal crystalline structure with $c=4.12 \mathrm{~A}^{\circ}, a=2.52 \mathrm{~A}^{\circ}$ but with keeping the same density than diamond $=3.51$ $\mathrm{g} / \mathrm{cm}^{3}[4]$.

Graphene is an amazing material [5] that was firstly discovered by Nobel Prize scientists; Andre Geim [6] and Konstantin Novoselov [7] in 2004. It is a carbon 2D material with one layer thickness [8-10] and seems to be useful in elaboration of nanoelectronic devices owing to its transport properties $[5,11-13]$.

Graphene is the most resistant material so far with elastic stiffness values $(340 \mathrm{~N} / \mathrm{m}$ : $2 \mathrm{nd}$ order; $-690 \mathrm{~N} / \mathrm{m}$ : 3rd order) [14]. It is considered as a semi-metal without a bandgap [15] with a carrier mobility equal to $10^{5}$ $\mathrm{cm}^{2} / \mathrm{V}$ which is greater than the value of silicon. This is

\footnotetext{
*Address correspondence to this author at the Research Unit on Materials, Processes and Environment, URMPE Unit, University M'hamed Bougara Boumerdes, 35000 Boumerdes, Algeria;

Tel: +213 247957 58; E-mail: t_razika@hotmail.com
}

why it is the most suitable to replace silicon in electronic devices [16]. Due to this behavior, it can be employed for all metallic contacts in solar cells and electronic devices [17-18]. It has also the advantage to have an elevated transparency [19] and thermal conductivity [20].

\section{Graphene in Solar Cells}

- The window layer in a solar cell has the key role to be conductive and transparent at the same time. The most commonly used materials for the window layer are indium tin oxide ITO and fluorine doped tin oxide FTO due to their high transparency and large bandgap [21-22]. However, they present the disadvantage of lack of transparency in the near infrared region in addition to the expensive cost of indium [21-22].

Here appears graphene as an alternative material for electrode contacts owing to its high transparency in the whole spectral range [23]. Graphene is then obtained by graphite oxide exfoliation and thermal reduction. It presents 550 $\mathrm{S} / \mathrm{cm}$ conductivity with $10 \mathrm{~nm}$ thickness. The transparency ranges around $70 \%$ in the interval $1000 \mathrm{~nm}$ to $3000 \mathrm{~nm}$. It is also interesting to mention that transparency may be increased to $80 \%$ just by reducing the thickness [23].

As example: The dye sensitized solar cell with $\mathrm{TiO}_{2}$ (electron transport) and spiro-OMeTAD ([2,20,7,70-tetrakis(N,N-di-p-methoxyphenylamine)9,90-spirobifluorene] (hole transport) with electrodes: graphene (anode) and gold 
(cathode). Its performance: $\mathrm{Jsc}=1.01 \mathrm{~mA} / \mathrm{cm}^{2}$, $\mathrm{Voc}=0.7 \mathrm{~V}, \mathrm{FF}=36 \%$ and $\eta=0.26 \%$ [23]. Compared to the same structure by replacing graphene with FTO: Jsc $=3.02 \mathrm{~mA} / \mathrm{cm}^{2}$, Voc $=$ $0.76 \mathrm{~V}, \mathrm{FF}=36 \%$ and $\eta=0.84 \%$.
The work function of graphene is $4.42 \mathrm{eV}$ [24] is closest to that of FTO electrode $4.40 \mathrm{eV}$ [25].

- $\quad$ The structure graphene/n-Si schottky junction acheived a conversion efficiency equal to $8.6 \%$ just by doping the graphene with
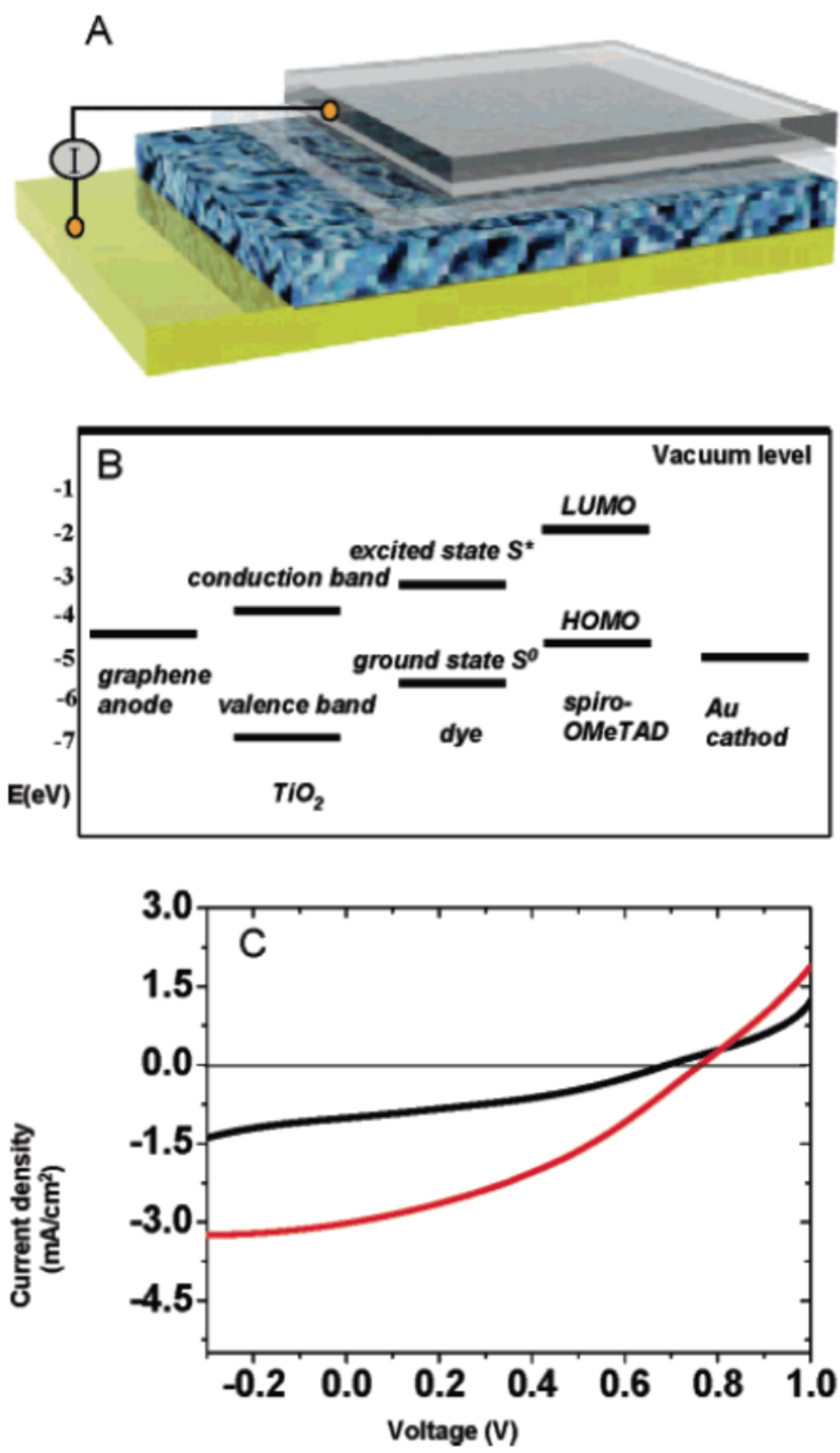

Figure 1: Illustration and performance of solar cell based on graphene electrodes. (A) Illustration of dye-sensitized solar cell using graphene film as electrode, the four layers from bottom to top are Au, dye-sensitized heterojunction, compact TiO2, and graphene film. (B) The energy level diagram of graphene/TiO2/dye/spiro-OMeTAD/Au device. (C) I-V curve of graphene-based cell (black) and the FTO-based cell (red), illuminated under AM solar light (1 sun). Reprinted with permission from (Xuan Wang, Linjie Zhi, and Klauss Müllen, "Transparent, conductive graphene electrodes for dye-sensitezed solar cells", Nanoletters, vol $8 \mathrm{n}^{\circ}$ 1, 2008, 232-327) copyright (2008) American Chemical Society [23]. 
bis(trifluoromethane sulfonyl) amide. It is mentioned that the structure without doping had conversion efficiency $\eta=1.9 \%$ [26]. The efficiency enhancement can be explained by the built-in voltage increase with doping.

There was other studies with the structures graphene on silicon, on cadmium sulfide and cadmium selenide [27-28, 18].

The corresponding efficiencies are presented in the table below:

- Grätzel dye sensitized solar cells with graphene as counter electrode, $\mathrm{Pt}$ free, exhibit a conversion efficiency of $7.59 \%$ [29].

- D.W. Zhang et al. used graphene nanosheets (GNs) to replace platinum in dye-synthetized solar cells [30]. They obtained very interesting results: With platinum: Jsc $=18.507 \mathrm{~mA} / \mathrm{cm}^{2}$, Voc $=0.714 \mathrm{~V}, \mathrm{FF}=57.51 \%$ and $\eta=7.59 \%$.

With GNs-annealed at $400^{\circ} \mathrm{C}$ : Jsc $=16.988$ $\mathrm{mA} / \mathrm{cm}^{2}$, Voc $=0.747 \mathrm{~V}, \mathrm{FF}=53.62 \%$ and $\eta=$ $6.81 \%[30]$.

$H$. Choi et al. followed many steps to process the dye sensitized solar cell device and found the parameters: Jsc $=5.6 \mathrm{~mA} / \mathrm{cm}^{2}, \mathrm{Voc}=0.76 \mathrm{~V}, \mathrm{FF}$ $=70 \%$ and $\eta=3.0 \%$ [31].

\section{DEPOSITION TECHNIQUES OF GRAPHENE}

The simplest and cheapest way to obtain graphene increase its attractivity to use it in all technological fields [32]. Graphene can be deposited by many techniques such as CVD (Chemical Vapor Deposition) [28] for transparent electrodes applications like in touch screens for example [20], or mechanically onto silicon as carried out by C.C. Chen et al. but only after removing the native silicon oxide following the wet and dry etching [27], or by chemical exfoliation [33], organic elaboration of graphene molecule [34], epitaxy [35], thermal exfoliation where graphite pellets were oxidized and exfoliated in a liquid phase solution [36-37], Laser ablation method [38] and spray-coating method [39].

\section{APPLICATIONS OF GRAPHENE}

\section{Biomedecine}

There are diverse applications of graphene such as biomedecine [40]: as we know, the materials based on carbon are biologically friendly compared to non organic materials. Biosensors based on Graphene Field Effect Transistor FET were successfully carried out [40] electrochemical double layer capacitors [41], smart windows [42].

\section{Energy Storage and Nanoelectronics}

Due to the fact that graphene presents an elevated fracture strain $\left(\sigma_{c}=9.51 \mathrm{GPa}\right)$, it is really suitable for flexible devices like organic electronics [39, 43]. In addition, the thermal conductivity of graphene provide the opportunity to the material to be employed for thermal dissipation in electronics.

\section{Photodetectors}

The high carrier mobility of graphene lead to quick photogenerated carriers with a bandwidth of $1.5 \mathrm{THz}$ making the material useful in photodetectors [44-45].

\section{Nanocomposite and Coatings}

It was found that the incorporation of graphene in composite materials enhance considerably their properties [20]. As example, one can avoid the rust deterioration of transport means such as cars and ships, just by inserting graphene into paint [32].

\section{CONCLUSION}

Graphene is a material that is making its way into all areas of technology. Thanks to its great properties, it is the ideal candidate for future electronic devices and materials used in painting, aviation, transportation, biomedicine and others.

The abundance of carbon and the ease of graphene's manufacture give it a place of choice to replace old materials. However, further research remains to be done to refine the conversion efficiency of solar cells based on graphene.

Table 1: Conversion Efficiency for Solar Cells Containing Graphene

\begin{tabular}{|c|c|c|c|}
\hline Structure & $\begin{array}{c}\text { Graphene-CdSe Nanobelt } \\
\text { Solar Cells [18] }\end{array}$ & $\begin{array}{c}\text { Graphene-CdS Nanowire Solar } \\
\text { Cells [28] }\end{array}$ & $\begin{array}{c}\text { Graphene-Silicon Schottky Diodes } \\
\text { [27] }\end{array}$ \\
\hline \hline $\begin{array}{c}\text { Conversion } \\
\text { efficiency }\end{array}$ & $0.1 \%$ & $1.65 \%$ & $2.86 \%$ \\
\hline
\end{tabular}




\section{REFERENCES}

[1] NN. Greenwood and A.Earnshaw, "Chemistry of the elements", Pergamon Press, February 1998.

[2] Hogh O. Pierson, "Handbook of carbon graphite, diamond and fullerenes: properties processing and applications", Noyes Publications, 1993 https://doi.org/10.1016/B978-0-8155-1339-1.50018-9

[3] Fritz Cirkel, " Graphite: propriétés, gisements, traitements, et usages", Fb\&c Limited, 2018.

[4] FB. Bundy, JS. Kasper; "hexagonal diamond: a new form of carbon"; the journal of chemical physics; vol 46 , number 9,1 may 1967

https://doi.org/10.1063/1.1841236

[5] AK. Geim, "Graphene: status and prospects", Science 19 Jun 2009; 324(5934): 1530-1534. https://doi.org/10.1126/science.1158877

[6] KS. Novoselov, AK. Geim, SV. Morozov, SV. Dubonos, Y.Zhang, D. Jiang, " Room-temperature electric field effect and carrier-type in graphene films", arXiv: cond-mat/0410631

[7] KS. Noroselov, AK. Geim, SV. Morozov, D. Jiang, Y. Zhang, SV. Dubonos, IV. Grigorieva, AA. Firso, "Electric field effect in atomically thin carbon films", arXiv: cond-mat/0410550.

[8] D. Roymayhew, J. Bozym, DC. Punckt, ACS nano 2010; 4: 6203-6211.

https://doi.org/10.1021/nn1016428

[9] Y. Zhu, S. Murali, W. Cai, X. Li, JW. Suk, JR. Potts, RS. Ruoff, " Graphene and graphene oxide; synthesis, properties, and applications"; advanced materials 2010, 22, 3906-3924. https://doi.org/10.1002/adma.201001068

[10] AK. Geim, KS. Novoselov, " The rise of graphene", Nature materials 2007; 6: 183-191 https://doi.org/10.1038/nmat1849

[11] KS. Novoselov, AK. Geim, SV. Morosov, D. Jiang, Y. Zhang, SV. Dubonos, IV. Grigorieva, AA. Firsov, "Electric field effect in atomically thin carbon films", Science 2004; 306: 666-669. https://doi.org/10.1126/science.1102896

[12] KS. Novoselov AK. Geim, SV. Morozov, D. Jiang, MI. Katsnelson, IV. Grigorieva, SV. Dubonos \& AA. Firsov." Two dimensional gas of massless Dirac fermions in graphene; Nature 2005; 438: 197-200. https://doi.org/10.1038/nature04233

[13] C. Berger, ZS. Tianbo, L. LiAsmerom, Y. OgbazghiRui, F. Zhenting, D. Alexei, NM. Edward, HC. Phillip, NF. Walt and A. de Heer, " Ultrathin epitaxial graphite: two dimensional electron gas properties and a route toward graphene based nanoelectronics", Journal of physical chemistry, 2004; B 108: $19912-19916$. https://doi.org/10.1021/jp040650f

[14] C. lee, X. Wei, JW. Kysar, J. Hone, " Measurement of the elastic properties and intrinsic strength of monolayer graphene" Science 321, 385 (2008). https://doi.org/10.1126/science.1157996

[15] A. Fargab, KB. Ranjeet and H. Yashil, "International journal of recent scientific research 2017; 8(5): 16893-16896.

[16] SV. Tkachev, E. Yu. Buslaeva and SP. Gubin, "Graphene: a novel carbon nanomaterial, Neoganicheskie Materialy 2011; 47(1): $5-14$

https://doi.org/10.1134/S0020168511010134

[17] Al. Aria, M.Gharib; " Graphene based multijunction flexible solar cell, united states patent application publication March 13, 2012; pp 2-8.

[18] L. Zhang, L. Fan, Z. Li, E. Shi, XM. Li, HB. Li, CY. Ji, Y. Jia, JQ. Wei, KL. Wang, HW. Zhu, DH. Wu, AY. Cao, Nano research 2011, 4, 891-900 https://doi.org/10.1007/s12274-011-0145-6

[19] XS. Li, YW. Zhu, WW. Cai, M Boryslak, BY. Han, D. Chen, RD. Piner, L.Colombo, RS. Ruoff, Nanoletters 2009; 12;
4359-4363

https://doi.org/10.1021/n1902623y

[20] S. Stankovich, DA. Dikin, GHB. Dommett, KM. Kohlhaas, EJ Zimney, EA. Stach, RD. Piner, ST. Nguyen \& RS. Ruoff, "Graphene-based composite materials", nature letters, vol 442, 20 july 2006/ doi:10.1038/nature04969, 282-286 https://doi.org/10.1038/nature04969

[21] S. Zhang, " Study of fluorine-doped tin oxide (FTO) for photovoltaic applications", Doctoral thesis, Communauté Université Grenoble Alpes, March 2017

[22] VK. Jain and AP. Kulshreshtha, " Indium-Tin-Oxide Transparent Conducting Coatings On Silicon Solar Cells And Their 'Figure Of Merit' "; SoLar Energy Materials 4 (1981) 151-158 https://doi.org/10.1016/0165-1633(81)90038-1

[23] X. Wang, L. Zhi, and K. Müllen, "Transparent, conductive graphene electrodes for dye-sensitezed solar cells", Nanoletters, vol $8 n^{\circ} 1,2008,232-327$ https://doi.org/10.1021/nl072838r

[24] R. Czerw, B. Foey, D. Tekleab, A. Rubeo, PM. Ajayan, DL. Carroll, Pysical Review B, 2002; 22: 367

[25] A. Anderson, N. Johansson, P. Bröms, N. Yu, D. Lupo, WR. Salaneck, Advanced Materials, 1999; 10: 859 https://doi.org/10.1002/(SICl)15214095(199808)10:11<859::AID-ADMA859>3.3.CO;2-T

[26] X. Miao, S. Tongay, MK. Petterson, K. Berke, AG. Rinzler BR. Appleton, AF. Hebard, "High efficiency graphene solar cells by chemical doping"; arXiv: 1209.0432v1 [condmat.mtrl-sci] 3 sep 2012

[27] CC. Chen, M. Aykol, CC. Chang, AFJ. Levi, SB. Cronin; "Graphene-silicon Schottky diodes"; Nanoletters 2011; 11: 1863-1867.

https://doi.org/10.1021/nl104364c

[28] Y. Te, Y. Dai, L. Dai, ZJ. Shi, N. Liu, F. Wang, L. Fu, RM Peng, XN. Wen, ZJ. Chen, ZF. Liu, GG. Qin; "HighPerformance Single CdS Nanowire (Nanobelt) Schottky Junction Solar Cells with Au/Graphene Schottky Electrodes";ACS Applied Materials International, 2010; 2: 3406-3410.

https://doi.org/10.1021/am1007672

[29] L. Kavan, JH. Yum and M. Grätzel, "Optically transparent cathode for dye-sensitized solar cells based on graphene nanoplatelets, ACS nano, 2011; 5(1): 165-172. https://doi.org/10.1021/nn102353h

[30] DW. Zhang, XD. Li, HB. Li, S. Chen, Z. Sun, XJ. Yin, SM Huang, "Graphene-based counter electrode for dyesensitized solar cells", Carbon 2011; 49: 5382-5388. https://doi.org/10.1016/j.carbon.2011.08.005

[31] Hyonkwang Choi, Hyunkook Kim, Sookhyun Hwang Wonbong Choi, Minhyon Jeon; " Dye-sensitized solar cells using graphene-based carbon nano-composite as counter electrode", Solar energy materials \& solar cells 2011; 95: 323-325

https://doi.org/10.1016/j.solmat.2010.04.044

[32] KS. Novoselov, VI. Fal'ko, L. Colombo, PR. Gellert, MG Schwab \& K. Kim; " A roadmap for graphene", Nature, vol 490, 11 october 2012, doi: 10.1038/nature11458, 192-200 https://doi.org/10.1038/nature11458

[33] S. Park, SR. Rodney, " Chemical methods for the production of graphene", natural nanotechnology, 2009, 4, 217-224. https://doi.org/10.1038/nnano.2009.58

[34] P. Kissel, R. Erni, WB. Schweizer, MD. Rossell, BT. King, T. Bauer, S.Gotzinger, AD. Schluter and J.Sakamoto; " A twodimensional polymer prepared by organic synthesis"; http://www.nature.com/doifinder/10.1038/nchem.1265.

[35] A. Oliveros, C. Coletti, SE. Saddow, " Chapter 12 - Carbon Based Materials on SiC for Advanced Biomedical Applications"; Silicon Carbide Biotechnology A Biocompatible Semiconductor for Advanced Biomedical Devices and 
Applications 2012, Pages 431-458. https://doi.org/10.1016/B978-0-12-385906-8.00012-X

[36] Y. Hernandez, V. Nicolosi, M. Lotya, FM. Blighe, Z. Sun, S. De, IT. McGovern, B. Holland, M. Byrne, YK. Gun'Ko, JJ. Boland, P. Niraj, G. Duesberg, S. Krishnamurthy, R. Goodhue, J. Hutchison, V. Scardaci, AC. Ferrari \& JN. Coleman; " high-yield production of graphene by liquid-phase exfoliation of graphite", Nature Nanotechnology 2008; 3: 563568

https://doi.org/10.1038/nnano.2008.215

[37] DR. Dreyer, RS. Ruoff and CW. Bielawski, " From conception to realization: an historical account of graphene and some perspectives for its future", Angew chemical international edition 2010; 49: 9336-9344. https://doi.org/10.1002/anie.201003024

[38] S. Dhar, A. Roy Barman, GX. Ni, X. Wang, XF. Xu, Y. Zheng, S. Tripathy, Ariando, A. Rusydi, KP. Loh, M. Rubhausen, AH. Castro Neto, B. O" zyilmaz, and T. Venkatesan, " A new route of graphene layers by selective laser ablation, AIP advances; 1, 022109 (2009) https://doi.org/10.1063/1.3584204

[39] Viet Hung Pham, Tran Viet Cuong, Seung Hyun Hur, Eun Woo Shin, Jae Seong Kim, Jin Suk Chung, Eui Jung Kim, "Fast and simple fabrication of a large transparent

[40] C. Ghung, YK. Kim, D. Shin, SR. Ryoo, BH. Hong, and DH. Min, " Biomedical applications of graphene and graphene oxide", Accounts of chemical research, 2013; 46(10): 2211-
2224.

https://doi.org/10.1021/ar300159f

[41] Y. Huang, J. Liang and Y. Chen, " An overview of the applications of graphene based-materials in super capacitors", small 2012, DOI: 10.1002/smll.201102635 chemically-converted graphene film by spray-coating": carbon 2010; 48: 1945-1951.

[42] F. Bonaccorso, Z. Sun, T. Hasan and AC Ferrari, " Graphene photonics and optoelectronics", Nature photonics, 2010; 4 611-622. https://doi.org/10.1038/nphoton.2010.186

[43] Z. Liu, Q. Liu, Y. Huang, Y. Ma, S. Yin, X. Zhang, W. Sun and Y. Chen; "OrganicPhotovoltaic Devices Based on a Novel Acceptor Material: Graphene"; Advanced materials, 2008; 20: 3924-3930. https://doi.org/10.1002/adma.200800366

[44] I. Meric, MY. Han, AF. Young, B. Ozyilmaz, P. Kim \& KL. Shepard; "Current saturation in zero-bandgap, topgatedgraphene field-effect transistors", nature nanotechnology 2008; 3: 654-659. https://doi.org/10.1038/nnano.2008.268

[45] P. Zhang, L. Ma, F. Fan, Z. Zeng, C. Peng, PE. Loya, Z. Liu, Y. Gong, J. Zhang, X. Zhang, PM. Ajayan, T. Zhu \& J. Lou: "Fracture toughness of graphene; "Fracture toughness of graphene"; nature communications, 5: 3782 , |www.nature.com/naturecommunications, 2014. https://doi.org/10.1038/ncomms4782

Received on 27-5-2019

Accepted on 19-7-2019

Published on 5-8-2019

DOI: http://dx.doi.org/10.31875/2410-2199.2019.06.7

(c) 2019 Razika Zair Tala-Ighil; Zeal Press.

This is an open access article licensed under the terms of the Creative Commons Attribution Non-Commercial License (http://creativecommons.org/licenses/by-nc/3.0/), which permits unrestricted, non-commercial use, distribution and reproduction in any medium, provided the work is properly cited. 